\title{
Treatment of underfed pigs with GH throughout the second quarter of pregnancy increases fetal growth
}

\author{
K L Gatford, J A Owens ${ }^{1}$, R G Campbell ${ }^{2}$, J M Boyce ${ }^{2}$, \\ P A Grant, M J De Blasio ${ }^{1}$ and P C Owens
}

\author{
Department of Obstetrics and Gynaecology, University of Adelaide, Adelaide, South Australia 5005, Australia \\ ${ }^{1}$ Department of Physiology, University of Adelaide, Adelaide, South Australia 5005, Australia \\ ${ }^{2}$ Bunge Meat Industries, PO Box 78, Corowa, New South Wales 2646, Australia \\ (Requests for offprints should be addressed to K L Gatford; Email: kgatford@physiol.adelaide.edu.au)
}

\begin{abstract}
Circulating growth hormone $(\mathrm{GH})$ concentrations increase in pregnancy and administration of $\mathrm{GH}$ during early-mid pregnancy increases fetal growth in well-fed pigs. To determine whether increased maternal GH could promote fetal growth when feed availability is restricted, fifteen cross-bred primiparous sows (gilts) were fed at approximately $30 \%$ of ad libitum intake, from mating onwards and were injected daily i.m. with recombinant porcine $\mathrm{GH}(\mathrm{pGH})$ at doses of $0,13.4 \pm 0.3$ and $25 \cdot 6 \pm 0 \cdot 5 \mu \mathrm{g} / \mathrm{kg}$ live weight from day 25 to day 51 of pregnancy (term $\sim 115$ days). Treatment with $\mathrm{pGH}$ increased maternal backfat loss between day 25 and day 51 of pregnancy, and increased maternal plasma IGF-I concentrations measured at day 51 of pregnancy. Fetal body weight, length and skull width at day 51 of pregnancy
\end{abstract}

were increased by maternal treatment with pGH. Fetal plasma glucose concentrations were increased and maternal/fetal plasma glucose concentration gradients were decreased by maternal pGH treatment at $13 \cdot 4$, but not $25 \cdot 6 \mu \mathrm{g} / \mathrm{kg}$.day. Fetal plasma concentrations of urea were decreased by both levels of pGH treatment. Overall, fetal weight was negatively correlated with fetal plasma concentrations of urea, positively correlated with maternal plasma $\alpha$-amino nitrogen concentrations and unrelated to glucose concentrations in either maternal or fetal plasma. This suggests that the availability of amino acids, not glucose, limits fetal growth in the first half of pregnancy in underfed gilts, and that maternal GH treatment may improve amino acid delivery to the fetus.

Journal of Endocrinology (2000) 166, 227-234

\section{Introduction}

Fetal growth rate is sensitive to the rates of placental delivery of nutrients and oxygen from maternal to fetal blood (Milner \& Gluckman 1996). This supply varies with the availability of circulating nutrients in the mother and with the efficiency of their transfer by the placenta to the fetus. Severe maternal undernutrition, particularly in early-mid pregnancy (Stein et al. 1995), or low protein intake in late pregnancy (Godfrey et al. 1996) reduces birth weight in humans. Conversely, maternal hyperglycaemia increases placental glucose transfer and birth weight in humans (Allen 1939, Cardell 1953, Hauguel et al. 1986) and in rats (Herrera et al. 1985). Conditions which reduce the availability of substrates (Godfrey et al. 1996, Noblet et al. 1985, Stein et al. 1995), or those which reduce nutrient delivery across the placenta (Owens et al. 1989), can retard fetal growth. However, increased feed supply throughout pregnancy in adolescent sheep promotes growth of maternal tissues, restricts growth of placenta and fetus and reduces birth weight (Wallace et al. 1996, 1997).
In humans, high carbohydrate intake in early pregnancy and low protein intake in late pregnancy are both associated with lower weights of placenta and infant at birth (Godfrey et al. 1996). Treatments that increase substrate concentrations in maternal plasma, or their transfer across the placenta may therefore increase fetal growth rate (Gluckman \& Harding 1997), whereas those that promote growth of maternal tissues may reduce placental and fetal growth (Wallace et al. 1996, 1997).

The maternal somatotropic axis may play a significant role in enabling the mother to adapt to and sustain pregnancy by coordinating nutrient use between maternal, placental and fetal tissues. Maternal blood concentrations of GH, IGF-I and/or IGF-II are increased during early or throughout all of pregnancy in a number of mammalian species (Donovan et al. 1991, Gargosky et al. 1990, Hills et al. 1996, Kelly et al. 1976, Mirlesse et al. 1993, Nason et al. 1996, Owens 1991, Sinha et al. 1990). Intrauterine growth retardation is associated with lower than normal concentrations of GH and IGF-I in maternal plasma in humans (Chowden et al. 1996, Lassarre et al. 1991, 
Mirlesse et al. 1993), whilst GH-deficiency in dams impairs fetal growth in rats (Spencer et al. 1994). This indicates that maternal GH and/or IGF-I are required for normal fetal growth. $\mathrm{GH}$ is not able to cross the placenta (Fholenhag et al. 1994), but elevated GH in pregnancy may promote fetal growth either by increasing maternal plasma glucose concentrations through its antagonistic effects on insulin action (Herrera et al. 1994) or by increasing placental capacity to transfer nutrients (Jenkinson et al. 1999). In growing non-pregnant pigs, $\mathrm{GH}$ treatment increases muscle growth and circulating levels of sugars, fatty acids, insulin and IGF-I, and reduces adipose deposition, even when feed is restricted by $20 \%$ to $40 \%$ below ad libitum rates (Buonomo et al. 1995, Campbell et al. 1988, Etherton et al. 1987, Gopinath \& Etherton 1989). In vitro, GH antagonises insulin-stimulated glucose uptake and lipogenesis in porcine adipose tissue (Magri et al. 1990, Walton \& Etherton 1986). However, the effects of $\mathrm{GH}$ administration on circulating metabolites and insulin sensitivity in pregnant pigs are unknown. Maternal GH may affect the placenta directly, or indirectly via increased circulating IGF-I, since the placenta expresses growth hormone receptors (Barnard et al. 1993, Frankenne et al. 1992, Scott et al. 1992) and type-1 IGF receptors (Chastant et al. 1994). Maternal GH treatment increases placental growth in early pregnant, well-fed pigs (Sterle et al. 1995) and in mid to late pregnant sheep (Stelwagen et al. 1994), and increases placental capacity for simple diffusion in late pregnant sheep (Harding et al. 1997).

Previous studies in pigs have observed different effects of maternal GH administration on fetal growth. This may reflect differences in the stage of pregnancy at which treatment occurred, the increase in maternal plasma $\mathrm{GH}$ achieved, the age and parity of the dam and the amount and type of feed provided. Birth weight of pigs was not responsive to an approximate three-fold increase in maternal GH concentrations during administration of $\mathrm{GH}$ from day 97 of pregnancy until term ( $\sim 115$ days $)$ in gilts and sows (Kveragas et al. 1986), nor to doubling of circulating GH following twice-daily injections with GHreleasing factor from day 102 of pregnancy until term in sows (Etienne et al. 1992). Treatment of primiparous sows with $\mathrm{GH}$ at 32 or $64 \mu \mathrm{g} / \mathrm{kg}$.day during the first quarter of pregnancy was originally reported to have no effect on fetal growth (Kirkwood et al. 1993), but others have since observed increased fetal and placental growth in gilts following maternal GH treatment at lower or similar doses commencing slightly later in early pregnancy (Kelley et al. 1995, Rehfeldt et al. 1996, Sterle et al. 1995). Daily administration of $6 \mathrm{mg}$ pGH to sows later in pregnancy, from day 80 to 94, increased birth weight of progeny (Rehfeldt et al. 1993). The aim of the present study was to determine whether GH treatment of pigs during the second quarter of pregnancy could promote fetal growth whilst the maternal anabolic response to $\mathrm{GH}$ was restrained using feed restriction.

\section{Materials and Methods}

\section{Animals}

The study was approved by the Animal Experimentation Ethics Committee of Bunge Meat Industries, Corowa. Fifteen crossbred (Large White $\times$ Landrace) gilts were bred at first oestrus to crossbred (Large White $\times$ Duroc) boars. They were fed $1.8 \mathrm{~kg} /$ day of a ration containing 13.5 MJ digestible energy per $\mathrm{kg}$ dry matter and $15.05 \%$ protein throughout pregnancy. This level of nutrition in the pregnant gilt corresponds to approximately $30 \%$ of ad libitum feed intake and permits maintenance of pregnancy and limited maternal live weight gain during pregnancy, but restricts fetal growth (Noblet et al. 1985). Live weight and backfat depth $(110 \mathrm{~mm}$ from the midline over the 13th rib, using B-mode live ultrasound) were measured at mating, day 25 of pregnancy and day 51 of pregnancy. Gilts were allocated to three treatment groups such that live weight and backfat depth at mating were not significantly different between treatment groups. The live weights and backfat depths of gilts were, respectively, $141.8 \pm 1.5 \mathrm{~kg}$ (mean \pm s.E.M.) and $18.7 \pm 2.4 \mathrm{~mm}$ at mating and $145 \cdot 3 \pm 1 \cdot 7 \mathrm{~kg}$ and $19 \cdot 6 \pm 3 \cdot 0 \mathrm{~mm}$ at day 25 of pregnancy. From day 25 to 50 of pregnancy, gilts received daily i.m. injections of $1 \mathrm{ml}$ of sterile water in the neck region, containing 0,2 , or $4 \mathrm{mg}$ pGH (recombinant porcine growth hormone, Southern Cross Biotech Pty. Ltd, Melbourne, Australia), which delivered average dose rates of pGH across the treatment period of $0,13 \cdot 4 \pm 0.3$ and $25 \cdot 6 \pm 0 \cdot 5 \mu \mathrm{g} / \mathrm{kg}$. day respectively. Gilts were bled via jugular venipuncture on day 51 of pregnancy, and then immediately sacrificed by injection of $20 \mathrm{ml}$ of $325 \mathrm{mg} / \mathrm{ml}$ pentobarbitone sodium (Lethabarb, Virbac (Aust.) Pty. Ltd, Peakhurst, NSW) into an ear vein. The uterine tract was immediately removed and weighed, and the fetuses removed. Blood was collected from the umbilical cord of each fetus. The weight, nose-tail length and skull width of each fetus was measured, and the fetal liver was dissected and weighed. Ponderal index of each fetus was calculated as weight/nose-tail length ${ }^{3}\left(\mathrm{~kg} / \mathrm{mm}^{3}\right)$.

\section{Circulating metabolite and hormone analyses}

Blood samples were collected into EDTA tubes on ice and plasma was obtained by centrifugation at $1800 \mathbf{g}$ for 10 min at $4{ }^{\circ} \mathrm{C}$. Plasma was stored at $-20{ }^{\circ} \mathrm{C}$. IGFs were extracted from plasma by size exclusion high performance liquid chromatography at $\mathrm{pH} 2 \cdot 5$, using a modification of the original procedure (Scott \& Baxter 1986), as described previously (Owens et al. 1990). IGF-I and IGF-II concentrations were determined by RIA of neutralised chromatography fractions devoid of IGFbinding proteins (Carr et al. 1995, Francis et al. 1989). Insulin was measured by radioimmunoassay (Insulin-CT kit, CIS bio international, Gif-sur-Yvette Cedex, France). 
Glucose (GLUC HK, cat. no. 073672 4, Roche Diagnostic Systems, Germany), urea (UREA, cat. no. 073685 6, Roche Diagnostic Systems, Germany), free fatty acids (NEFA C, cat. no. 279-75401, Wako Pure Chemical Industries, Osaka, Japan), triglycerides (TRIG, cat. no. 073679 1, Roche Diagnostic Systems, Basel, Switzerland), and cholesterol (CHOL, cat. no. 073663 5, Roche Diagnostic Systems, Germany) were also measured in maternal and fetal plasma. Amino nitrogen concentrations in maternal and fetal plasma were measured by colorimetric assay (Evans et al. 1993). Maternal/fetal transplacental concentration gradients for glucose and urea were calculated by dividing the concentration in maternal plasma by that in fetal plasma.

\section{Western ligand blot analysis of circulating IGF-binding proteins}

IGF-binding proteins in plasma collected from all gilts were individually measured by Western ligand blot analysis following incubation with ${ }^{125}$ I-labelled IGF-II as described previously (Owens et al. 1991). Densitometric analysis was performed using the software package MacBas $2 \cdot 2$ (Fuji Film Corporation, Tokyo, Japan), and density values for each binding protein were expressed relative to the density of the $50 \mathrm{kDa}$ binding protein in a reference sample included in each analysis. The density value for IGFBP-3 was obtained by summing the density values for the 45 and $50 \mathrm{kDa}$ binding proteins, which have been identified by immunoblotting and sequencing as isoforms of pIGFBP-3 (Walton \& Etherton 1989). Other binding proteins on these blots have been previously identified as IGFBP-1 (29 kDa) and IGFBP-2 (34.5 kDa), based on their co-migration during electrophoresis with binding proteins purified from other species (Owens et al. 1991).

\section{Statistics}

The effects of treatment on dams were analysed by oneway ANOVA (Program 7D, BMDP Statistical Software, Inc., USA). Treatment group means were compared with the control group by $t$-test using Bonferroni's correction for multiple comparisons. Measurements of individual fetuses were treated as repeated measures on each dam. Fetal measurements were analysed using an unbalanced repeated measures method (Program 5 V, BMDP Statistical Software, Inc., LA, USA), for treatment effects using litter size as a covariate. Where treatment effects were significant, data was further analysed to determine the relationship between pGH dose and responses, using the unbalanced repeated measures method with linear and quadratic contrasts for the dose of $\mathrm{pGH}$ administered, with litter size as a covariate. This model was progressively reduced to exclude non-significant factors. Associations were analysed by linear regression.

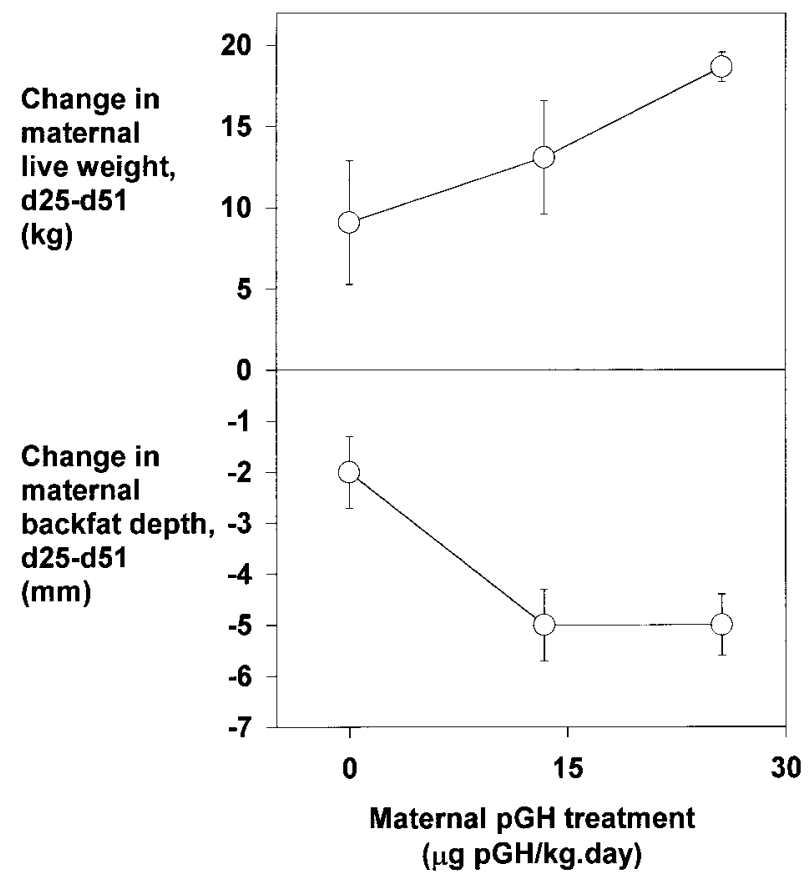

Figure 1 Effect of maternal pGH treatment on change in maternal live weight and backfat depth. Data are presented as mean \pm S.E.M. Change in live weight and back fat depth are from days 25 to 51 of pregnancy. Treatment group means were compared with the control group by $t$-test using Bonferroni's correction for multiple comparisons. Change in maternal live weight did not differ between treatment groups $(P>0 \cdot 1)$. The loss of maternal backfat was increased by treatment with either dose of $\mathrm{pGH}(P<0 \cdot 05)$.

\section{Results}

Maternal live weight gain over the treatment period did not differ between treatment groups $(P>0 \cdot 1$, Fig. 1), but was weakly positively correlated with pGH dose $(r=+0 \cdot 52, n=15, P=0 \cdot 045)$. Loss of maternal backfat over the treatment period was more than doubled by either dose of pGH $(P<0 \cdot 01$, Fig. 1). The change in maternal backfat depth per unit live weight was negatively correlated with fractional (\%) weight gain of dams $(r=-0.69$, $n=15, P<0 \cdot 005)$.

Administration of $\mathrm{pGH}$ to pregnant gilts did not alter the concentrations of glucose $(5 \cdot 23 \pm 0 \cdot 16 \mathrm{mmol} / \mathrm{l})$, urea $(4 \cdot 65 \pm 0.23 \mathrm{mmol} / \mathrm{l})$, triglycerides $(0 \cdot 81 \pm 0.07 \mathrm{mmol} / \mathrm{l})$, $\alpha$-amino nitrogen $(4.03 \pm 0.17 \mathrm{mmol} / \mathrm{l})$ or cholesterol $(2 \cdot 24 \pm 0.07 \mathrm{mmol} / \mathrm{l})$ in maternal plasma. Maternal plasma concentrations of urea and cholesterol were strongly positively correlated with each other $(r=+0 \cdot 74, n=15$, $P=0.0015)$. Concentrations of free fatty acids in maternal plasma were $60-75 \%$ lower in dams treated with pGH (Fig. 2), and overall were strongly negatively correlated with both fractional (\%) weight gain of dams $(r=$ $-0 \cdot 68, n=15, P=0 \cdot 005)$ and maternal plasma $\alpha$-amino nitrogen $(r=-0.85, n=15, \quad P<0 \cdot 0002)$, and strongly 


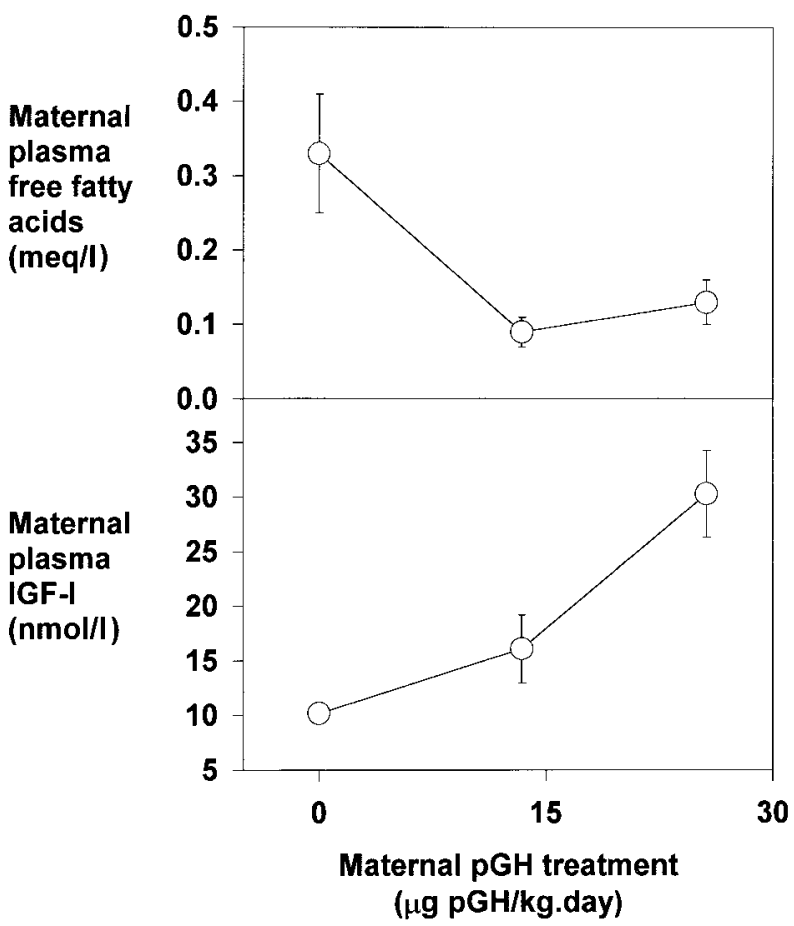

Figure 2 Effect of maternal pGH treatment on maternal plasma concentrations of free fatty acids and IGF-I at day 51 of pregnancy. Data are presented as mean \pm S.E.M. Treatment group means were compared with the control group by t-test using Bonferroni's correction for multiple comparisons. Maternal plasma free fatty acid concentrations were decreased by treatment at either $\mathrm{pGH}$ dose $(P<0 \cdot 05)$. Maternal plasma IGF-I concentrations were increased in gilts treated with the higher dose of $\mathrm{pGH}(P<0 \cdot 001)$, but not in gilts treated with the lower pGH dose $(P>0 \cdot 1)$.

positively correlated with the change in maternal backfat depth per unit live weight $(r=+0 \cdot 73, n=15, P<0 \cdot 002)$. Maternal plasma $\alpha$-amino nitrogen was also strongly positively correlated with fractional (\%) weight gain of dams $(r=+0 \cdot 78, n=15, P<0 \cdot 001)$. Maternal plasma concentrations of IGF-I were increased three-fold (Fig. 2) by $\mathrm{pGH}$ treatment at $25.6 \mu \mathrm{g} / \mathrm{kg}$.day. Maternal plasma IGF-II $(65.3 \pm 2.8 \mathrm{nmol} / \mathrm{l})$ and insulin $(22.9 \pm 4.0 \mathrm{IU} /$ $\mathrm{ml}$ ) concentrations were not affected by pGH administration. Maternal insulin and glucose concentrations were strongly positively correlated $(r=+0 \cdot 77, n=15, P<0 \cdot 001)$. Administration of $\mathrm{pGH}$ had no effect on maternal plasma concentrations of IGF-binding proteins as assessed by Western ligand blot analysis of plasma from individual pregnant gilts (data not shown). A Western blot of IGF-binding proteins in maternal plasma pooled from each treatment group is presented in Fig. 3. Fractional (\%) weight gain of pregnant gilts was not related to either IGF-I or IGF-II $(P>0 \cdot 1)$ but was positively correlated with the total IGF concentration (sum of IGF-I plus IGF-II $)$ in maternal plasma $(r=+0 \cdot 63, n=15, P=0 \cdot 012)$. The total plasma IGF concentration in mothers was also

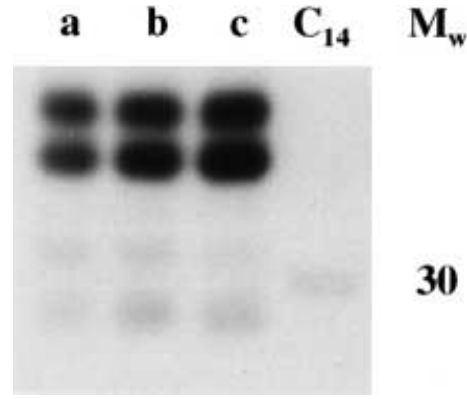

Figure 3 Effect of maternal pGH treatment on the IGFBP profile at day 51 of pregnancy in maternal plasma pooled from gilts treated with (Lane a) 0, (Lane b) 13.4 or (Lane c) $25 \cdot 6 \mu \mathrm{g} \mathrm{pGH/kg.day.}$ Lane $\mathrm{C}_{14}$ shows molecular weight markers, with the visible band corresponding to a molecular weight of 30 kilodaltons.

negatively correlated with the change in maternal backfat depth per unit live weight during treatment $(r=-0.59$, $n=15, P=0 \cdot 02)$ and the concentration of free fatty acids in maternal plasma $(r=-0 \cdot 65, n=15, P=0 \cdot 009)$, and was strongly positively correlated with the concentration of $\alpha$-amino nitrogen in maternal plasma $(r=+0 \cdot 86, n=15$, $P<0 \cdot 001)$. Maternal plasma IGF-I $(r=+0 \cdot 65, n=15, P=$ $0 \cdot 008)$ and total IGF concentrations $(r=+0 \cdot 64, n=15$, $P=0 \cdot 009)$ were both positively correlated with maternal plasma insulin concentrations. Maternal plasma IGF-II concentrations were correlated positively with maternal plasma $\alpha$-amino nitrogen $(r=+0 \cdot 74, n=15, P<0 \cdot 002)$ and negatively with maternal plasma free fatty acids $(r=-0.53, n=15, P<0 \cdot 05)$.

Weight of the uterus and contents $(8.1 \pm 0.6 \mathrm{~kg})$, and litter size $(11 \cdot 1 \pm 0 \cdot 6$ fetuses/dam $)$ were not altered by maternal pGH administration. Fetal body weight, liver weight, and skull width increased $(P<0 \cdot 0001)$ with increasing dose of pGH administered to the mother (Fig. 4). Fetal weight, liver weight, and skull width were increased by $18 \%, 26 \%$ and $6 \%$ respectively in pregnant gilts treated with $25.6 \mu \mathrm{g} \mathrm{pGH} / \mathrm{kg}$.day. When adjusted for litter size, fetal length was increased by $5 \%$ in gilts treated with $25.6 \mu \mathrm{g} \mathrm{pGH} / \mathrm{kg}$.day (Fig. 4). Maternal GH dose was positively correlated with fetal liver weight in absolute terms $(r=+0 \cdot 45, n=166, P<0 \cdot 0001)$, and as a proportion of fetal body weight $(r=+0 \cdot 25, n=166, P<0 \cdot 0001)$. Average fetal weight per litter was negatively correlated $(r=-0 \cdot 60, n=15, P=0 \cdot 017)$ with the change in maternal backfat depth during the treatment period (Fig. 5). Both litter size $(r=-0.54, n=15, P<0.05)$ and total body weight of fetuses per dam $(r=-0 \cdot 55, n=15, P<0 \cdot 05)$, but not body weights of individual fetuses were negatively correlated with glucose concentrations in maternal plasma. Overall, fetal weight was also weakly positively correlated with the concentration of $\alpha$-amino nitrogen in maternal plasma $(r=+0 \cdot 169, n=166, P=0 \cdot 03)$.

Fetal plasma glucose concentrations changed in a quadratic fashion $(P=0 \cdot 015)$ with the dose of $\mathrm{pGH}$ 


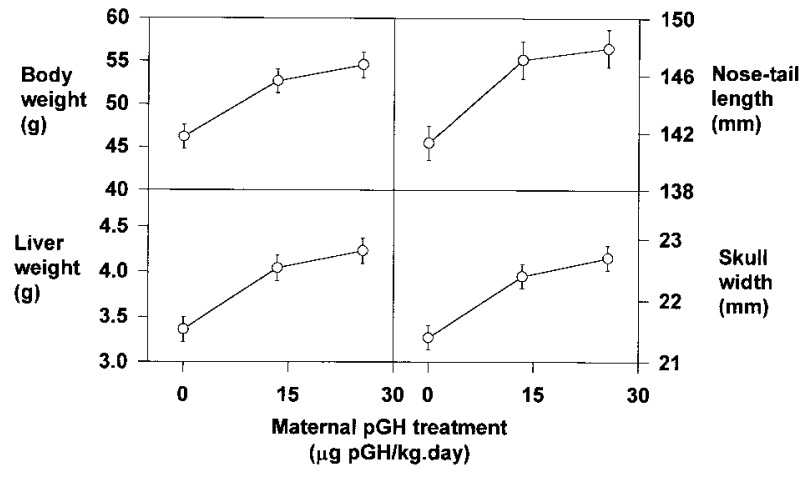

Figure 4 Effect of maternal pGH treatment on fetal weight and size at day 51 of gestation. Data are presented as mean \pm S.E.M. Means for fetal length are adjusted to a litter size of $11 \cdot 1$ fetuses. Fetal weight, liver weight and skull width increased linearly with increasing dose of $\mathrm{pGH}$ administered to the mother $(P<0 \cdot 0001)$. Fetal length was positively related to maternal $\mathrm{pGH}$ dose $(P=0.0003)$ and negatively related to litter size $(P=0.038)$.

administered to the pregnant gilt (Fig. 6). This change in fetal plasma glucose concentrations was accompanied by a change in the maternal/fetal plasma glucose concentration gradient in gilts treated with $13.4 \mu \mathrm{g} \mathrm{pGH} / \mathrm{kg}$.day $(P=0 \cdot 036)$. Fetal plasma urea concentrations decreased linearly with increasing dose of pGH $(P=0 \cdot 0002)$, accompanied by a linear increase in the maternal/fetal plasma urea concentration gradient $(P=0 \cdot 003)$. The maternal/fetal plasma urea concentration gradient also increased with litter size $(P=0 \cdot 005)$. Fetal plasma concentrations of urea were negatively correlated with fetal weight $(r=-0 \cdot 34, n=138, P<0 \cdot 0001)$ and with the concentration of glucose in maternal plasma $(r=-0 \cdot 26$, $n=139, P=0 \cdot 0018)$, and were positively correlated with maternal plasma concentrations of urea $(r=+0 \cdot 52, n=139$,

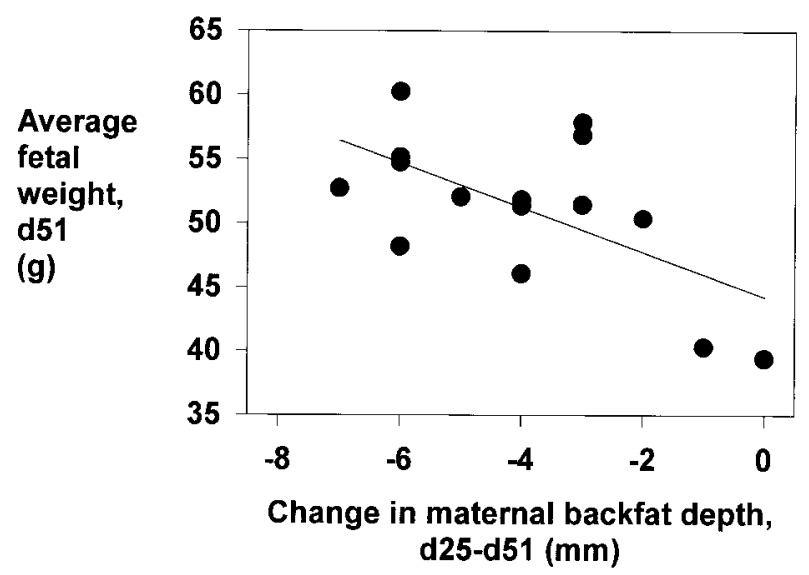

Figure 5 Average fetal weight per litter at day 51 of gestation increases with increasing loss of maternal backfat during $\mathrm{GH}$ treatment period. Average fetal weight at day 51 of gestation was negatively correlated with change in maternal backfat depth during the treatment period $(r=-0 \cdot 60, n=15, P=0 \cdot 017)$.

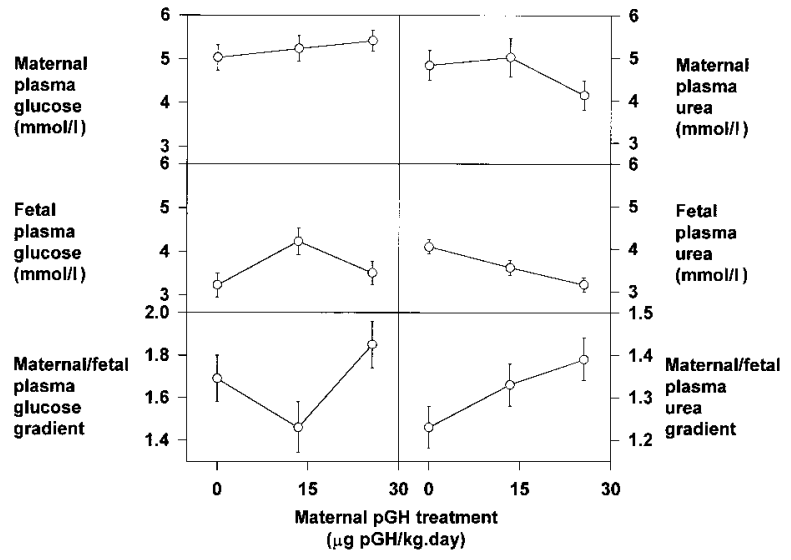

Figure 6 Effect of maternal pGH treatment on concentrations of glucose and urea in fetal plasma, and on fetal:maternal glucose and urea concentration gradients at day 51 of gestation. Data are presented as mean \pm S.E.M. Means for maternal/fetal plasma urea concentration gradient are adjusted to a litter size of $11 \cdot 1$ fetuses. Maternal plasma glucose and urea concentrations were not affected by pGH treatment $(P>0 \cdot 01)$. Fetal plasma glucose concentrations $(P=0.015)$ and maternal/fetal plasma glucose concentration gradient $(P=0.036)$ changed in a quadratic fashion with the dose of $\mathrm{pGH}$ administered to the pregnant gilt. Fetal plasma urea concentrations decreased $(P=0 \cdot 0002)$ and maternal/fetal plasma urea concentration gradient increased $(P=0.003)$ linearly with increasing dose of $\mathrm{pGH}$. The maternal/fetal plasma urea concentration gradient also increased linearly with increasing litter size $(P=0.005)$.

$P<0 \cdot 0001)$ and cholesterol $(r=+0 \cdot 29, n=139, P<0 \cdot 001)$, and with fetal plasma glucose concentrations $(r=+0 \cdot 36$, $n=139, \quad P<0 \cdot 0001)$. No significant associations were observed between fetal plasma glucose and either fetal weight or maternal plasma glucose concentrations.

Administration of $\mathrm{pGH}$ to the pregnant gilt did not affect fetal plasma concentrations of IGF-I $(1 \cdot 79 \pm$ $0 \cdot 06 \mathrm{mmol} / \mathrm{l})$ or IGF-II $(20 \cdot 2 \pm 0 \cdot 7 \mathrm{mmol} / \mathrm{l})$. Fetal weight at day 51 of gestation was not related to fetal plasma IGF-I concentration overall $(P>0 \cdot 8)$ or within treatment groups. Overall, there was a negative association between fetal plasma IGF-II and fetal weight at day 51 of gestation $(r=-0 \cdot 29, \quad n=118, P=0 \cdot 002)$. Fetal plasma concentrations of IGF-I and IGF-II were positively correlated with each other $(r=+0 \cdot 47, n=118, P<0 \cdot 0001)$.

\section{Discussion}

Administration of $\mathrm{GH}$ to feed restricted pigs throughout the second quarter of their first pregnancy increased maternal backfat loss and plasma IGF-I concentrations, and decreased maternal plasma FFA concentrations. Maternal weight gain and plasma amino acid concentrations were positively correlated with $\mathrm{GH}$ dose. The dose of $\mathrm{GH}$ required to affect changes in maternal weight and fat 
depth is lower in the pregnant gilt than in the nonpregnant growing pig. In this study, treatment with GH more than doubled the rate of loss of backfat at an average dose of either 13.4 or $25.6 \mu \mathrm{g} \mathrm{pGH} / \mathrm{kg}$.day. In contrast, doses of $30 \mu \mathrm{g} \mathrm{pGH} / \mathrm{kg}$.day failed to decrease carcass lipid content in non-pregnant growing pigs, and a dose of $70 \mu \mathrm{g}$ $\mathrm{pGH} / \mathrm{kg}$.day decreased carcass lipid by 25\% (Etherton et al. 1987). This suggests that pregnancy enhances the sensitivity of pigs to the antilipogenic effects of $\mathrm{GH}$. In contrast, pregnancy induces GH resistance in rats (Chiang \& Nicoll 1991, Gargosky et al. 1991).

Maternal anabolic and catabolic responses to $\mathrm{GH}$ were strongly correlated. As maternal weight gain increased, fat loss and plasma amino acid concentrations increased, and plasma FFA concentrations decreased. Maternal responses to exogenous $\mathrm{GH}$ are probably direct responses to $\mathrm{GH}$, and not due to actions of IGF-I, since treatment of pigs with IGF-I only promotes growth during the neonatal period (Schoknecht et al. 1997, Walton et al. 1995). However, maternal anabolism (weight gain, plasma $\alpha$-amino nitrogen concentration) and antilipogenesis (loss of maternal backfat, plasma FFA concentrations) were related to the total IGF concentrations in maternal blood. The major site of increased IGF-I gene expression in GH-treated pregnant pigs is the liver (Sterle et al. 1998), suggesting that increased maternal plasma concentrations of IGF-I in the present study reflect increased hepatic IGF-I synthesis.

Fetal weight (body weight, liver weight) and size (length, biparietal diameter) were increased by pGH treatment of mothers in the present study. Maternal GH treatment does not affect fetal growth in well-nourished rats (Gargosky et al. 1991), and decreases (Chiang \& Nicoll 1991) or fails to restore fetal growth (Woodall et al. 1999) in undernourished pregnant rats. Previous studies of the effects of administration of $\mathrm{pGH}$ in well-fed pregnant pigs at similar doses to those used in the present study and at similar stages of gestation have also demonstrated increases in fetal growth. Sterle et al. (1995) reported a 10\% increase in fetal weight following GH treatment of well-fed gilts with $32 \mu \mathrm{g} \mathrm{pGH} / \mathrm{kg}$.day from day 30 to day 43 of pregnancy, whilst Kelley et al. (1995) reported a 20\% increase in fetal length, but no change in fetal weight, following treatment of ad libitum-fed gilts with 15 or $30 \mu \mathrm{g}$ pGH/kg.day between days 28 and 40 of pregnancy. Greater fetal growth responses to maternal GH administration during early-mid gestation in our study than those previously reported (Kelley et al. 1995, Sterle et al. 1995) may partially reflect the greater degree of maternal undernutrition in our study. This may have produced slower rates of fetal growth and constrained maternal anabolic responses to $\mathrm{GH}$. In the present study, gilts were fed at $1.8 \mathrm{~kg} /$ day of a ration containing $13.5 \mathrm{MJ}$ digestible energy $/ \mathrm{kg}$ and $15 \cdot 05 \%$ protein, whilst Kelley et al. (1995) fed gilts a similar diet at $3 \cdot 3 \mathrm{~kg} /$ day, and Sterle et al. (1995) fed gilts at $2 \cdot 3$ to $2 \cdot 7 \mathrm{~kg} /$ day.
Maternal GH treatment probably increases fetal growth via changes in maternal metabolism, rather than by acting at the placenta. Porcine placenta contains few GH receptors at this stage of pregnancy, and administration of GH to pigs from day 30 to 43 of pregnancy does not increase IGF-I mRNA in uterus or placenta (Sterle et al. 1998). However, maternal GH treatment also stimulates hepatic IGF-I synthesis, and this IGF-I may affect placental growth or function via placental IGF-I receptors (Chastant et al. 1994). Sterle et al. (1995) showed increases in placental as well as fetal weight in response to maternal $\mathrm{GH}$ treatment at this stage of pregnancy in pigs, and suggested that fetal growth was increased in part by enhancing placental size and transport capacity. It is possible that placental function was enhanced by maternal GH treatment in this study, at least at the lower dose of GH used, since fetal plasma glucose concentrations were increased, and maternal/fetal glucose gradient was decreased in gilts treated with $13 \cdot 4 \mu \mathrm{g} \mathrm{pGH} / \mathrm{kg}$.day. However, fetal weight was not correlated with fetal plasma glucose or the maternal/fetal glucose gradient, implying that glucose is not the nutrient which limits fetal growth in the undernourished pregnant pig, and that improved placental glucose transport was not the major mechanism for increased fetal growth in response to maternal $\mathrm{GH}$ treatment. We therefore suggest that maternal GH treatment increased fetal growth by increasing availability to the fetus of an alternative growth-limiting nutrient, probably via increased maternal plasma concentrations. Fetal growth was increased and plasma concentrations of urea were decreased in fetuses from sows treated with both doses of $\mathrm{pGH}$, suggesting that protein catabolism may be decreased in these fetuses, and that the supply of alternative fuels for oxidation is increased by both doses of pGH. The concentrations of free fatty acids in maternal plasma at day 51 of pregnancy were decreased, and maternal plasma concentrations of glucose, urea and triglycerides were unaltered by $\mathrm{GH}$ treatment. Maternal plasma $\alpha$-amino nitrogen concentrations were positively correlated with GH dose and with fetal weight, suggesting that GH treatment may increase fetal growth by increasing the supply of one or more amino acids which limit fetal growth.

We did not observe changes in fetal plasma IGF-I or IGF-II in response to maternal pGH treatment, despite increases in fetal growth. This suggests that maternal GH administration at low doses increased fetal growth through improved nutrient availability to the fetus, without nutritional modulation of the fetal endocrine IGF axis. At day 51 of gestation, fetal weight was not correlated with fetal plasma IGF-I, but was negatively correlated with fetal plasma IGF-II across all treatment groups. Later in gestation (from day 70), fetal serum concentrations of both IGF-I and IGF-II have been shown to correlate positively with fetal weight in pigs (Hausman et al. 1991), but relationships between fetal plasma IGFs and growth have not been reported during early gestation in the pig. 
In summary, treating the underfed gilt with 13.4 or $25.6 \mu \mathrm{g} \mathrm{pGH} / \mathrm{kg}$.day during the second quarter of pregnancy increased fetal weight, whilst also increasing maternal backfat loss. This suggests that $\mathrm{pGH}$ is able to at least partially overcome any maternal constraints to fetal growth brought about by restricted feeding of the sow during pregnancy. We hypothesise that maternal GH treatment increases fetal growth through changes in maternal metabolism which increase the availability of amino acids to the fetus.

\section{Acknowledgements}

This research was supported in part by the Pig Research \& Development Corporation, Australia. KLG was supported by a Pig Research \& Development Corporation Postdoctoral Scholarship. The authors thank Dave Harrison for assistance with animal studies and Linda Mundy for performing the metabolite assays.

\section{References}

Allen E 1939 The glycosurias of pregnancy. American Journal of Obstetrics and Gynecology 38 982-991.

Barnard RJ, Southard N, Edens A \& Talamantes F 1993 Growth hormone receptor and growth hormone-binding protein messages in mouse placenta contain the exon analogous to human exon 3 . Endocrinology 133 1474-1477.

Buonomo FC, Klindt J \& Yen JT 1995 Administration of porcine growth hormone by sustained-release implant: Growth factor and metabolic responses in crossbred white and genetically lean and obese boars and gilts. Journal of Animal Science 73 1318-1326.

Campbell RG, Steele NC, Caperna TJ, McMurtry JP, Solomon MB \& Mitchell AD 1988 Interrelationships between energy intake and endogenous porcine growth hormone administration on the performance, body composition and protein and energy metabolism of growing pigs weighing 25 to 55 kilograms live weight. Journal of Animal Science 66 1643-1655.

Cardell BS 1953 The infants of diabetic mothers: a morphological study. Journal of Obstetrics and Gynaecology of the British Empire 60 834-853.

Carr JM, Owens JA, Grant PA, Walton PE, Owens PC \& Wallace JC 1995 Circulating insulin-like growth factors (IGFs), IGF-binding proteins (IGFBPs) and tissue mRNA levels of IGFBP-2 and IGFBP-4 in the ovine fetus. Journal of Endocrinology 145 545-557.

Chastant S, Monget P \& Terqui M 1994 Localization and quantification of insulin-like growth factor-I (IGF-I) and IGF-II/mannose-6-phosphate (IGF-II/M6P) receptors in pig embryos during early pregnancy. Biology of Reproduction $\mathbf{5 1}$ $588-596$.

Chiang MH \& Nicoll CS 1991 Administration of growth hormone to pregnant rats on a reduced diet inhibits growth of their fetuses. Endocrinology 129 2491-2495.

Chowden JA, Evain-Brion D, Pozo J, Alsat E, Garcia-Segura LM \& Argente J 1996 Decreased expression of placental growth hormone in intrauterine growth retardation. Pediatric Research 39 736-739.

Donovan WH, Giudice LC, Murphy LJ, Hintz RL \& Rosenfeld RG 1991 Maternal insulin-like growth factor-binding protein messenger ribonucleic acid during rat pregnancy. Endocrinology 129 3359-3366.
Etherton TD, Wiggins JP, Evock CM, Chung CS, Rebhun JF, Walton PE \& Steele NC 1987 Stimulation of pig growth performance by porcine growth hormone: Determination of the dose-response relationship. Journal of Animal Science 64 433-443.

Etienne M, Bonneau M, Kann G \& Deletang F 1992 Effects of administration of growth hormone-releasing factor to sows during late gestation on growth hormone secretion, reproductive traits, and performance of progeny from birth to 100 kilograms live weight. Journal of Animal Science 70 2212-2220.

Evans PC, Ffolliott-Powell FM \& Harding JE 1993 A colorimetric assay for amino nitrogen in small volumes of blood: reaction with $\beta$-napthoquinone sulphonate. Analytical Biochemistry 208 334-337.

Fholenhag KI, Sandstrom IM, Malmlof K, Skottner AI \& Nyberg FJ 1994 Human growth hormone does not cross the placenta of the pregnant rat. Growth Regulation 4 181-187.

Francis GL, Owens PC, McNeil KA, Wallace JC \& Ballard FJ 1989 Purification, amino acid sequences and assay cross-reactivities of porcine insulin-like growth factor-I and -II. Journal of Endocrinology 122 681-687.

Frankenne F, Alsat E, Scrippo ML, Igout A, Hennen G \& EvainBrion D 1992 Evidence for the expression of growth hormone receptors in human placenta. Biochemical and Biophysical Research Communications 182 481-486.

Gargosky SE, Moyse KJ, Walton PE, Owens JA, Wallace JC, Robinson JS \& Owens PC 1990 Circulating levels of insulin-like growth factors increase and molecular forms of their serum binding proteins change with human pregnancy. Biochemical and Biophysical Research Communications 170 1157-1163.

Gargosky SE, Owens JA, Walton PE, Owens PC, Wallace JC \& Ballard FJ 1991 Administration of insulin-like growth factor-I, but not growth hormone, increases maternal weight gain in late pregnancy without affecting fetal or placental growth. Journal of Endocrinology 130 395-400.

Gluckman PD \& Harding JE 1997 The physiology and pathophysiology of intrauterine growth retardation. Hormone Research 48 (Suppl 1) 11-16.

Godfrey K, Robinson S, Barker DJP, Osmond C \& Cox V 1996 Maternal nutrition in early and late pregnancy in relation to placental and fetal growth. British Medical Journal 312 410-414.

Gopinath R \& Etherton TD 1989 Effects of porcine growth hormone on glucose metabolism of pigs: I. Acute and chronic effects on plasma glucose and insulin status. Journal of Animal Science $\mathbf{6 7}$ 682-688.

Harding JE, Evans PC \& Gluckman PD 1997 Maternal growth hormone treatment increases placental diffusion capacity but not fetal or placental growth in sheep. Endocrinology 138 5352-5358.

Hauguel S, Desmaizieres V \& Challier JC 1986 Glucose uptake, utilization, and transfer by the human placenta as functions of maternal glucose concentration. Pediatric Research 20 269-273.

Hausman GJ, Campion DR \& Buonomo FC 1991 Concentration of insulin-like growth factors (IGF-I and IGF-II) in tissues of developing lean and obese pig fetuses. Growth, Development and Aging 55 43-52.

Herrera E, Palacin M, Martin A \& Lasuncion MA 1985 Relationship between maternal and fetal fuels and placental glucose transfer in rats with maternal diabetes of varying severity. Diabetes 34 (Suppl 2) $42-46$.

Herrera E, Munoz C, Lopez-Luna P \& Ramos P 1994 Carbohydratelipid interactions during gestation and their control by insulin. Brazilian Journal of Medical and Biological Research 27 2499-2519.

Hills FA, English J \& Chard T 1996 Circulating levels of IGF-I and IGF-binding protein-1 throughout pregnancy: relation to birthweight and maternal weight. Journal of Endocrinology 148 303-309.

Jenkinson CMC, Min SH, MacKenzie DDS, McCutcheon SN, Breier BH \& Gluckman PD 1999 Placental development and fetal growth in growth hormone-treated ewes. Growth Hormone and IGF Research 9 11-17. 
Kelley RL, Jungst SB, Spencer TE, Owsley WF, Rahe CH \& Mulvaney DR 1995 Maternal treatment with growth hormone alters embryonic development and early postnatal growth of pigs. Domestic Animal Endocrinology 12 83-94.

Kelly PA, Tsushima T, Shiu RPC \& Friesen HG 1976 Lactogenic and growth hormone-like activities in pregnancy determined by radioreceptor assays. Endocrinology 99 765-774.

Kirkwood RN, Peacock AJ \& Thacker PA 1993 The influence of growth hormone injections either pre- or post-breeding on the reproductive performance of sows and gilts. Canadian Journal of Animal Science 73 259-265.

Kveragas CL, Seerley RW, Martin RJ \& Vandergrift WL 1986 Influence of exogenous growth hormone and gestational diet on sow blood and milk characteristics and on baby pig blood, body composition and performance. Journal of Animal Science $\mathbf{6 3}$ 1877-1887.

Lassarre C, Hardouin S, Daffos F, Forestier F, Frankenne F \& Binoux M 1991 Serum insulin-like growth factors and insulin-like growth factor binding proteins in the human fetus. Relationships with growth in normal subjects and in subjects with intrauterine growth retardation. Pediatric Research 29 219-225.

Magri KA, Adamo AM, LeRoith D \& Etherton TD 1990 The inhibition of insulin action and glucose metabolism by porcine growth hormone in porcine adipocytes is not the result of any decrease in insulin binding or insulin receptor kinase activity. Biochemistry Journal 266 107-113.

Milner RDG \& Gluckman PD 1996 Regulation of intrauterine growth. In Pediatrics and Perinatology. The Scientific Basis, edn 2, pp 284-289. Eds PD Gluckman \& MA Heymann. London: Arnold.

Mirlesse V, Frankenne F, Alsat E, Poncelet M, Hennen G \& Evain-Brion D 1993 Placental growth hormone levels in normal pregnancy and in pregnancies with intrauterine growth retardation. Pediatric Research 34 439-442.

Nason KS, Binder ND, Labarta JI, Rosenfeld RG \& Gargosky SE 1996 IGF-II and IGF-binding proteins increase dramatically during rabbit pregnancy. Journal of Endocrinology 148 121-130.

Noblet J, Close WH, Heavens RP \& Brown D 1985 Studies on the energy metabolism of the pregnant sow. 1. Uterus and mammary tissue development. British Journal of Nutrition 53 251-265.

Owens JA 1991 Endocrine and substrate control of fetal growth: Placental and maternal influences and insulin-like growth factors. Reproduction, Fertility and Development 3 501-517.

Owens JA, Falconer J \& Robinson JS 1989 Glucose metabolism in pregnant sheep when placental growth is restricted. American Journal of Physiology 257 R350-R357.

Owens PC, Johnson RJ, Campbell RG \& Ballard FJ 1990 Growth hormone increases insulin-like growth factor (IGF-I) and decreases IGF-II in plasma of growing pigs. Journal of Endocrinology 124 269-275.

Owens PC, Conlon MA, Campbell RG, Johnson RJ, King R \& Ballard FJ 1991 Developmental changes in growth hormone, insulin-like growth factors (IGF-I and IGF-II) and IGF-binding proteins in plasma of young growing pigs. Journal of Endocrinology 128 439-447.

Rehfeldt C, Fiedler I, Weikard R, Kanitz E \& Ender K 1993 It is possible to increase skeletal muscle fibre number in utero. Bioscience Reports 13 213-220.

Rehfeldt C, Kuhn G, Kanitz E, Schneider F, Vanselow J, Fuerbass R, Nuemberg G, Beyer M \& Ender K 1996 Fetal growth and skeletal muscle development in response to growth hormone treatment during early gestation. Journal of Animal Science $\mathbf{7 4}$ (Suppl 1) 142.

Schoknecht PA, Ebner S, Skottner A, Burrin DG, Davis TA, Ellis K \& Pond WG 1997 Exogenous insulin-like growth factor-I increases weight gain in intrauterine growth-retarded neonatal pigs. Pediatric Research 42 201-207.

Scott CD \& Baxter RC 1986 Production of insulin-like growth factor $\mathrm{I}$ and its binding protein in rat hepatocytes cultured from diabetic and insulin-treated diabetic rats. Endocrinology 119 2346-2352.

Scott P, Kessler MA \& Schuler LA 1992 Molecular cloning of the bovine prolactin receptor and distribution of prolactin and growth hormone receptor transcripts in fetal and utero-placental tissues. Molecular and Cellular Endocrinology 89 47-58.

Sinha YN, Klemke HG, Maurer RR \& Jacobsen BP 1990 Changes in the glycosylated and nonglycosylated forms of prolactin and growth hormone in lean and obese pigs during pregnancy. Endocrinology 127 410-418.

Spencer GSG, Robinson GM, Berry CJ \& Dobbie PM 1994 Alteration of maternal growth hormone levels during pregnancy influences both fetal and postnatal growth in rats. Biology of the Neonate 66 112-118.

Stein AD, Ravelli ACJ \& Lumey LH 1995 Famine, third trimester pregnancy weight gain, and intrauterine growth: The Dutch famine birth cohort study. Human Biology 67 135-150.

Stelwagen K, Grieve DG, Walton JS, Ball JL \& McBride BW 1994 Effect of bovine somatotropin administration during the last trimester of gestation on maternal growth, and foetal and placental development in primigravid ewes. Animal Production 58 87-94.

Sterle JA, Cantley TC, Lamberson WB, Lucy MC, Gerrard DE, Matteri RL \& Day BN 1995 Effects of recombinant porcine growth hormone on placental size, fetal growth, and IGF-I and IGF-II concentrations in pigs. Journal of Animal Science $\mathbf{7 3}$ 2980-2985.

Sterle JA, Boyd CK, Peacock JT, Koenigsfeld AT, Lamberson WB, Gerrard DE \& Lucy MC 1998 Insulin-like growth factor (IGF)-I, IGF-II, IGF-binding protein-2 and pregnancy-associated glycoprotein mRNA in pigs with somatotropin-enhanced fetal growth. Journal of Endocrinology 159 441-450.

Wallace JM, Aitken RP \& Cheyne MA 1996 Nutrient partitioning and fetal growth in rapidly growing adolescent ewes. Journal of Reproduction and Fertility 107 183-190.

Wallace JM, Da Silva P, Aitken RP \& Cruickshank MA 1997 Maternal endocrine status in relation to pregnancy outcome in rapidly growing adolescent sheep. Journal of Endocrinology 155 359-368.

Walton PE \& Etherton TD 1986 Stimulation of lipogenesis by insulin in swine adipose tissue: Antagonism by porcine growth hormone. Journal of Animal Science 62 1584-1595.

Walton PE \& Etherton TD 1989 Effects of porcine growth hormone and insulin-like growth factor-I (IGF-I) on immunoreactive IGF binding protein concentration in pigs. Journal of Endocrinology $\mathbf{1 2 0}$ 153-160.

Walton PE, Dunshea FR \& Ballard FJ 1995 In vivo actions of IGF analogues with poor affinities for IGFBPs: Metabolic and growth effects in pigs of different ages and GH responsiveness. Progress in Growth Factor Research 6 385-395.

Woodall SM, Breier BH, Johnston BM, Bassett NS, Barnard R \& Gluckman PD 1999 Administration of growth hormone or IGF-I to pregnant rats on a reduced diet during pregnancy does not prevent fetal intrauterine growth retardation and elevated blood pressure in adult offspring. Journal of Endocrinology 163 69-77.

Received 22 February 1999

Revised manuscript received 20 December 1999 Accepted 16 February 2000 